NB: This paper is a pre-publication version that appears in lieu of the publisher's own version of record.

\title{
Judging Jack: Rethinking historical agency and the sport hero
}

\begin{abstract}
One aspect of the dizzying (aesthetic, cultural, linguistic, visual, and post-modern) ${ }^{1}$ 'turns' Sport history has taken in recent times has been the revision/deconstruction of sporting heroes and demystification of historical narratives. This, in turn, has attended to larger historical concerns about the centrality of agents and agency in narrative making. ${ }^{2}$ Encouraged by these directions, this paper reconsiders the primacy afforded agents and their agency within national Olympic history creation. I examine revered 1930s track athlete Jack Lovelock who features predominantly within New Zealand's Olympic history. ${ }^{3}$ The paper aims to prompt contemplation about sport heroes. In particular, I argue sport historians should continue to decentre sport figures and bring alternate meanings, interpretations, and renderings of agents to the fore.
\end{abstract}

\section{Key words:}

Jack Lovelock, New Zealand, agency, sport hero 


\section{Judging Jack: Rethinking historical agency and the sport hero}

\section{Introduction}

Sport history, like other humanities fields, has undergone dizzying (aesthetic, cultural, linguistic, visual, and post-modern) 'turns' in recent years that have opened space for projects that challenge the field's conventional epistemes, contents, and its potentialities. ${ }^{4}$ Accordingly, some sport historians are hard at work contemplating these theoretical and methodological twirls, which, they hope, will alter the nature of the discipline and lead to innovative, inspiring, and creative advances, and, challenges, to its futures. A particular feature of their undertakings has been the revision/deconstruction of sport figures/idols/hero(in)es, ${ }^{5}$ which in turn, has attended to larger historical concerns about the centrality of agents and agency in historiography. Agents (those individuals and groups assigned centrality within historical projects), Callinicos remarks, are a substantial component of the framework of narrative making. ${ }^{6}$ Historians' selections and use of agents, for instance, bears heavily on the narrative contours and the meanings readers deduce about the historical moment(s) under investigation. This process is evident in sport history scholarship.

Similar to mainstream history, sport historians typically select agents who have, for potentially innumerable reasons, affected some sort of political, social, or cultural agency in their life and/or work (boxers Muhammad Ali, Jim Jeffries, and Jack Johnson, tennis player Althea Gibson, Hawaiian surfer Duke Kahanamoku, and runners Roger Bannister and Ben Johnson are all popular choices). ${ }^{7}$ Such individuals, and even whole groups such as female cyclists in the early nineteenth century, ${ }^{8}$ are crafted as integral characters in historical plots, protagonists or provocateurs of progress, and, often treated (appropriately or otherwise) as hagiographic subjects. For the likes of researchers such as Bale, Hughson, Nathan, and others (who I discuss below), the focus is on developing better appreciations for, and scholarly sensitivity and sensibility toward, the reconstruction, evocation, meaning and fallibility of historical figures. Encouraged by these directions, and bearing in mind current disciplinary deviations, this paper advances arguments about reconsidering the primacy afforded certain agents and their agency, 
and that ignored of others within sport history. The specific interest here is with John ('Jack') Edward Lovelock; an agent in the early history of New Zealand's Olympic Committee (NZOC).

Primary details of Lovelock's life have already been well documented. ${ }^{9}$ To rehearse key contextual facts: Lovelock was born on January $5^{\text {th }} 1910$ in Crushington (a minute mining town in a rural part of the South Island of New Zealand's West Coast). In 1924 his educational trajectory took him to Timaru Boy's High School where displayed not only academic aptitude, but also, superior athletic talent. Lovelock's scholarly prowess and sporting proficiency were further developed during his studies as a medical student at the University of Otago, Dunedin. In 1931, Lovelock was awarded a Rhodes scholarship which he undertook at Exeter College, Oxford. As at Otago, Lovelock matched his studies with participation in the University's and United Kingdom's amateur athletic scene. Following his graduation in 1934 as a medical practitioner, Lovelock concomitantly continued participating in international athletic events over the 1500m and 1 mile distances; most notably, the 1932 Los Angeles Olympic Games, the 1934 British Empire Games in London, and, the 1936 Olympic Games. Following his gold medal $1500 \mathrm{~m}$ win in 1936 Lovelock embarked on a tour of America, and then, a government sponsored trip to New Zealand during the Southern Hemisphere summer of 1936/37. This point effectively marked the end of his athletic career. Lovelock subsequently served as a Major in the Royal Army Medical Corps during World War Two, then, relocated to the United States where he continued medical work in New York City. He died on December 281949 after falling from a subway platform. ${ }^{10}$

The paper begins with an examination of agents and agency in historical narratives. Within histories of sport organizations, such as NZOC, attention is often given to prominent administrators who can be identified as protagonists (or sometimes antagonists) from archival records. Their related agency, particularly in affecting stability or change, is also usually easier to discern than that of other, perhaps more peripheral, characters. Accordingly, this paper treats Lovelock as a somewhat obscure agent; never an official administrator, but, a proficient 1930s New Zealand track athlete and doctor. Of particular interest to the discussion on agency is the significant role Lovelock served as NZOC's informal, well respected, athletics advisor. I 
evaluate Lovelock to make a case for challenging the definitional scope of agents, and concomitantly, acknowledging possibilities for agency to be found among a wider array of characters and/or groups (rather than the usual administrators). Lovelock was well respected on account of his sporting prestige, and his status as one of the country's sport heroes, coupled with his scientific/scholarly expertise, meant that he was frequently listened to by the upper echelons of athletic administration. Lovelock's career as an athlete and medical professional, for instance, enabled him to contribute to NZOC's philosophies, policies, practices, and ethos and objectives during the interwar years. Drawing on his Northern hemisphere experiences, Lovelock also forewarned NZOC of some of the possible challenges it was likely to face in the future (such as the need for more rigorous training regimes). While Lovelock has been revered for his track triumphs, his administrative agency has received little attention.

I contend here that the ability to rethink/remake Lovelock as a different sort of agent, and accepting his place within a broader understanding of agent, rests on first transcending the myopicism of the heroic Lovelock, and, allowing alternative renderings to come to the fore. I present an example of such an approach from outside the discipline toward the end of the paper, and also, refer to another creative historiographical approach within the discipline to further encourage scholars to think about agency more broadly and play with agents in new ways.

\section{Considerations on the messiness of agents}

Sport history is awash with all sorts of agents; from iconic characters ascribed central narrative roles and who affect substantial action and reactions in the primary plot, to more subsidiary and peripheral figures lurking in the shadows of the subplot and influencing the historical trajectory in less discernible ways. Jack Lovelock, for example, is one of the earliest eponyms of a New Zealand national sporting hero. In New Zealand's Olympic histories Lovelock has been a privileged agent (his legendary status as iconic national hero, for example, invariably far exceeds his sporting prowess). Yet, similar to the likes of Roger Bannister, or figures such as Pierre de Coubertin (who I discuss shortly), the rhetoric of Lovelock as an athletic 'legend' has distorted appreciation for the (possibly more mundane) reality of his existence, or, critical, 
alternative, interpretations of his agency. Accordingly, I use the example of Lovelock to argue that we need to engage with agents more innovatively. That is, to appreciate their inherently complicated, and oft contradictory, character subjectivities and subtleties, to better contextualize their lives, highlight their political struggles, and, critique the consequences of their existence and the meaning makings they are a part of. There are, however, some important caveats and considerations that need to be made before I progress.

As Marwick reminds us in his model of contextualization, human agents matter. ${ }^{11}$ The actions and consequences of particular individuals, and groups of individuals, Marwick suggests, are as fundamental to an understanding of history as major forces and constraints, ideologies, and events. In his examination of the 1960s, Marwick argues historians investigating specific contexts should pay close attention to agents, especially major agents who have had the most discernable influence(s) on particular courses of events. Marwick is more concerned in his examination with 'majorities, not minorities', 12 that is, presidents, heads of state, and political figures, than he is other members/groups of society. I concur with Marwick that attending to agents helps personalize our narratives and interpretations of history which may otherwise remain lifeless. Moreover, historians who choose to focus on agents, as Munslow suggests, believe in their ability to gauge the intentions behind human actions (through a detailed knowledge of the archival remains of such agency'. ${ }^{13}$

I am conscious that the arguments put forth in this paper are predicated on a particular, and invariably narrow, conceptualization of both 'agent' and 'agency'. The decision to focus on Lovelock's position as a prime agent of New Zealand's 1930s sporting scene is based on an understanding that athletes (specifically, popular and successful examples thereof) are, through their actions, constituent players in contouring selected/selective historical moments. My focus on Lovelock's agency, in this instance, is useful as it enables me to establish discussion about how historians might advance their critique of 'the (sport) hero' in their narratives. To this end, I offer a tri-fold conceptualization of Lovelock as 'The professional', 'The administrator', and, 'The alternative and anti-' (which I detail later). I accept that there are many different forms of agent, and indeed processes of agency, than I exclusively focus on here. In the establishment of 
modern sport in New Zealand, for example, Booth focuses on wider categories of agents: Urban reformers, Old Boys of the Public School system, business owners and entrepreneurs. ${ }^{14}$ Historians, researchers and authors, too, also serve as distinct forms of agents. Their agency manifests explicitly in their choice of subject matter and archival sources, and, implicitly in their narrative choices. ${ }^{15}$ This sort of agency has be extended by Gary Fine with his articulations of the 'reputational entrepreneur'; a specific form of political/politicized narrator who effectively have the means, motive and opportunity to affect directional shifts in a/the popular historical consensus. ${ }^{16}$ Mindful of this, I acknowledge that those working with agents need to tread carefully. My purpose here is to demonstrate how more marginal characters might be considered agents, or, at least included in a broader categorization of who might be ascribed agency.

The attention given to Lovelock as an NZOC agent does not, of course, deny structural components. Indeed, I appreciate that both agents and structures matter. For, as Callinicos reminds us, 'social structures typically involve relationships among actors' (emphasis in the original). ${ }^{17}$ The creation of NZOC, for instance, was not merely a by-product materializing out of the ether of the seemingly inevitable revolutions of the modern sport industry, but rather, was predicated on the interactions of specific individuals therein and their interfaces within, through, and across social processes. I am also cogniscent of Levine, Sober, and Wright's warnings about historical explanations that emphasize agency (or what Callinicos and others also refer to as methodological individualism). ${ }^{18}$ Figuring agents out, they suggest, and affording them a central place in historical narratives, needs to be approached cautiously. Agents, they remind us, matter in and of themselves, but not necessarily at the total exclusion of all other explanations.

Thus, agent focused histories need not be all about the individual(s). Indeed, the best agencyorientated narratives at the very least value, and attempt to explain, the idiosyncrasies of social structures and their influences on individuals' lives and experiences; the affects and effects of which are not always easy to discern. I recognize that agents motives, desires, intentions, actions and conflicts exist within, and are shaped by, structural conditions (that they contribute 
to creating); and, that these very conditions imbue agents with forms of power that allow them to react to those very processes. As Callinicos expresses, we need to reconceptualise historical agents; to take 'persons seriously as initiators of action - with the idea that social structures (for example, capitalist relations of production) have causal powers'. ${ }^{19}$ The outcomes of which, and to evoke Carr, are to 'come up with a satisfying account of the actions, whether we call it explanation, understanding, or just description, which somehow tells us more than we knew before'.$^{20}$ If, as I encourage through this paper, we want make waves in how we deal with, and represent, sport agents in our works, then definitions of Carr's 'satisfying account', I argue, should better embrace - and still with a nod toward disciplinary rigor - liberal, creative, daring, imaginative, and evocative scholarly persuasions. I will return to these thoughts in the latter section of this paper.

Other scholars working with Olympic figures have also expressed concern over the agency ascribed to Olympic characters. A recent examination of Pierre de Coubertin, alleged renovator of the modern Olympic Games, is a useful example of the need to interrogate the limits of autonomy in individual agents, and, rethink the significance of agency within historical projects. The International Olympic Committee lauds Coubertin as the patriarch of the Olympic movement - a man whose love of English sport cultures, broader pacifist sensibilities, and access to a network of European colleagues, allegedly nurtured his profound vision and plan for the rebirth of the Olympic Games. As a counterpoint to this dominant narrative, French scholar, Patrick Clastres has recently uncovered a different Coubertin. ${ }^{21}$

Drawing on a critical reading of Coubertin's memoires and the broader philosophical and political context in Europe, Clastres classifies Coubertin an opportunist. Clastres argues Coubertin did not hold a deeply considered philosophical position, but rather, appropriated a pre-existing set of educational and political schemas of the time for his own advantage. In the first instance Coubertin was, Clastres suggests, blessed by insightful mentors who were busy propagating physical education pedagogy in France. Among this group were Jules Simon and Frederic le Play. ${ }^{22}$ It was entirely fortunate, Clastres contends, that Coubertin encountered the grand reformers working in the larger context of cultural and educational changes. ${ }^{23}$ Even if 
Coubertin leads one to believe in his own memoires that he acted alone, Clastres stresses, he was but a pawn in a contest between two pedagogical lobbies: British educationalists (who promoted competitive sport as a virtuous and civilizing endeavor) and French educationalists (who conceptualized sport as a way to restore the physical vitality of the upper classes). In sum, Coubertin was not the autonomous individual agent responsible for the renovation of the Olympic Games. Rather, Coubertin was simply someone who knew how to assess the prevailing intellectual zeitgeist and manipulate it to suit his own political ends. ${ }^{24}$ Clastres' examination reminds us that in the context of broader social and cultural forces historians need to take particular care before assigning agency to specific individuals. His thoughts about imperfect historical figures, including those afforded hero(ic) status, are useful as we proceed.

\section{The agency of the sport hero}

To better understand Lovelock's specific contributions as an agent, a detour to consider the notion of the sport hero as a particular form of agent here is helpful. Clastres' indictment of Coubertin, for instance, echoes the efforts of other scholars within the history and sociology of sport fields to continually rethink historical sporting figures. ${ }^{25}$ Three who offer particularly relevant remarks, and urge us to more carefully critique the primacy afforded sport history's seminal agents, are John Bale, John Hughson, and Dan Nathan. ${ }^{26}$ Bale, for example, critiques highly regarded British middle-distance runner, Roger Bannister, and the myth of the four minute mile (a feat he achieved on May 6 1954). Bale's work is useful in that it signaled a need to think, write and conceive of history in new and innovative ways. For Bale the issue of agency is central to how historians revise popular (and oft misguided) assumptions about nations' sporting pasts (in this case, the arbitrary construction of the four-minute barrier, and, the associated prestige afforded Bannister for his subsequent achievements). ${ }^{27}$ Bannister was, Bale contends, 'not the much loved hero that some suggest' ${ }^{28}$ Critiquing a much loved popular figure will, Bale acknowledges, provoke some scholars to label his history as revisionist. To recall Carr's earlier sentiments, revisionist history is not synonymous with poor history. For Bale, revisionist history is not about disputing 'facts', but providing explanations, and within 
these explanations, 'simply challenging accepted descriptions, causes, and consequences of historical representations'. ${ }^{29}$

Bale, for example, sets out to destroy the notion that Bannister was an 'amateur gentleman' and 'hero'. Bale sees these particular concepts as slippery, ambiguous, muddy, and fraught with tension and confusion. The concepts are of little use in helping Bale 'explain' Bannister's complex character. In his interpretation, Bale also poses a number of 'what if' scenarios - what he terms, 'a brief counterfactual history'. ${ }^{30}$ In doing so, he emphasises that the myth and memory of Bannister as a sport star is entirely fallible, and moreover, his agency in 'breaking' the ambiguous four-minute marker is not as phenomenal as might first be presumed. As such, it is difficult to 'read' Bannister as an exceptional sport hero as he 'was not all that different from other runners who preceded him, or from his contemporaries'. ${ }^{31}$ Bale's intention is not to critique Bannister's athletic performance per se, rather to enable readers 'to think about a significant moment in Britain's sporting past and perhaps even re-evaluate it'. ${ }^{32}$

This encouragement to consider the fallibility of sport figures, or at least, to better contextualize their socio-cultural significance and characterization as heroes, has been furthered by Hughson. ${ }^{33}$ In historical narratives, for instance, sport heroes are constructed as key agents; that is, as particular (and often peculiar) protagonists whose agency (as evidenced through a combination of their athletic prowess, humanistic endeavors, philanthropy, or, (im)moral actions) is idolized and idealized to the extreme. Sport figures, Hughson reminds us, may be spectacular or exceptional for multitude reasons. The academic concern, rather, is with the historical tendency to over-valorize their physical actions and ignore (or downplay) the complexities of the historical milieu to which their athletic prowess and political agency is a part. 'The "exaggerated veneration" of the hero', Hughson contests, 'can lead to the abnegation of human responsibility and, at the very least, profound disappointment for the hero-worshipper once the fallibility of the idol is eventually revealed'. ${ }^{34}$ Ascribing sport figures hero status should, Hughson asserts, necessarily involve consideration of the sport hero as cultural hero. In keeping with a sense of heroic tradition, 'sporting heroes', for Hughson, should 
possess an 'historical sense' of their achievement and in some cases this extends beyond the realm of sport to the cultural historical significance of sport in their time' ${ }^{35}$

The desire to redress ways historians make and remake sporting figures, and acknowledge (or deny) the concomitant broader socio-political concerns, has also been taken up by Nathan in his work on the infamous Black Sox baseball scandal which involved the indictment of several baseball players who were found guilty of match fixing during the 1919 World Series. ${ }^{36}$ The scandal spurred public disgust toward professional baseball players and eventually forced structural changes on the sport. At the time, Nathan recalls, the sport possessed some exceptional stars such as Eddie Cicotte, Arnold Gandil, Joe Jackson and others. However, their heroics on the field, and the ways in which they were popularized by the public, did not absolve them of their part (central, peripheral, ambivalent or otherwise) in the scandal. Nathan's concern with the Black Sox is not so much in the heroic or anti-heroic actions of players and administrative, or their lack or abundance of moral resolve, but rather on using the events of 1919 to stress the importance of carefully contextualized historical narratives. Such approaches would take into account the slipperiness of memory making, the unavoidable human foibles of historical agents, and, historian's particular subjectivities.

To summarize here, whether Bannister, Black Sox members, or other sporting icons, broadening the conceptualization of the sport hero affords opportunities to render, read, and recreate athletic agents anew. Such reconstructions, while still paying homage to physical prowess, more appropriately recognise the inherently complex (and often fraught) nature of athletes' human condition, and, the dialectical and dynamic relationship with the context(s) to which they were invariably a part. 'While heroic figures do not', to recall Hughson here, 'exist apart from the societies from which they receive adoration, the very notion of hero suggests leadership, innovation and superiority in a way that places the hero above the common person and his/her quotidian existence'. ${ }^{37}$ The historian has a key role to play in this process. Via the historian's work, sport heroes are, I acknowledge, crafted as considerable agents in popular culture/cultural life (though usually with an emphasis on their prowess and popularity). A consequence of these sorts of narrative constructions may, at times inadvertently, be that 
athlete's roles in the specific development and machinations of their associated sport organization may be less pronounced. Sports heroes do, I respect, typically possess a form of agency in their ability to engender public affectation and media interest. Yet, in some cases, as with Lovelock, their 'hero' status - as I craft, for example, in my historical narrative here - also affords alternate forms of agency within the political structures of their sport.

\section{Locating Lovelock}

Analysing the socio-political complexities of sporting figures requires not only an intricate understanding of the individual(s) in question, but also, an ability to locate the subject within a broader national, trans-national, and international milieu. Thus, and to recall Hughson, the reading of Lovelock entertained hereon is predicated on first situating the athlete within the prevailing sporting zeitgeist and cultural context of the 1930s both in New Zealand and further abroad. ${ }^{38}$ The era, as is well known, was contoured by the primary global economic and political forces; namely, The Great Depression, subsequent efforts by nations to restore their economic vitality, border conflicts and uncertainties, and, concomitant resurgences in overt nationalism and nation building. ${ }^{39}$ An invariable component of this reinvigoration of global relationships was concerted investments into fostering fraternities in and through sport. As Keys argues, drawing on Anderson's earlier theorizing on nationalism, in the decades preceding World War Two nations came to be defined as 'imagined communities'. ${ }^{40}$ Within this imaginary sport became, Keys furthers, a transcendental space; a place where emotive passions and affective fervor coalesced relatively easily with nationalistic jingoism (and its counter point, xenophobic discourse). ${ }^{41}$ With its centrality to the expression of national vitality and vigor, the world of international sport expanded rapidly. Mainstays such as the Olympics underwent economic and administrative transformation and newer events, such as the soccer world cup, piqued international curiosities. $^{42}$

Britain, and its companions and Dominions (e.g., New Zealand, Australia, Canada and South Africa) were, too, complicit in these practices. One particularly significant event in this regard was the establishment of the Empire Games. ${ }^{43}$ During the politically anxious times of the 1930s the Empire Games became not only an alternate spectacle to the larger Olympic Games, but 
also, a key mechanism that helped reaffirm Britain's wider political might and imperial strength. In New Zealand, the country's sporting administrators (certainly those in the Olympic Committee and Rugby Federation, among other sport organisations) were particularly keen to maintain their engagement in international sporting competitions. ${ }^{44}$ Such occasions not only served to demonstrate and showcase the country's athletic talent and sporting prowess, but also, provided opportunities to reaffirm transnational sporting friendships and rivalries (many of which had their antecedents in imperial conviviality and military comradeship). To this end, Olympic administrators in New Zealand greeted the introduction of the Empire Games with enthusiasm. The Empire Games enhanced the sporting calendar and created substantial opportunities for New Zealand athletes; even those such as Lovelock who had migrated abroad. $^{45}$

As the 1930 progressed, sport administrators in New Zealand remained largely indifferent to the fragile state of affairs in Europe, choosing rather to concentrate on the increasingly burdensome logistical and financial pragmatics of sending successful teams of athletes to compete overseas and uphold the country's sporting profile. Their efforts were aided considerably, in this regard, by expatriate, Dr Arthur Porritt, the recently elected IOC member to New Zealand who resided in London. ${ }^{46}$ In the 1930s Porritt served as an important conduit of information and expertise for the New Zealand Olympic Committee (and latterly New Zealand Olympic and British Empire Games Association). In the lead up to the 1936 Olympics, for example, Porritt reassured colleagues back in New Zealand that the Germans (sic) were on track to arrange superb games with excellent facilities, and, that New Zealand athletes should forward to competing there. ${ }^{47}$ Porritt's affirmations were also reinforced by Lovelock; with who he had developed a firm friendship. Although 10 years Porritt's junior, Lovelock was also an accomplished athlete, fellow Rhodes Scholar, medical professional, and, an expatriate. ${ }^{48}$ The mutual interests the two men shared, in particular their affectations for New Zealand, were certainly borne out in their efforts to ensure the country's athletes not only achieved their best internationally, but also, were cast as positive emblems of the nation's imperial (British) heritage ${ }^{49}$ Lovelock's own participation, and success, in 1936, thus was not merely the personal achievement of an accomplished individual, but rather, enmeshed within encompassing 
discourses of national identity, imperialism, (post-)colonialism, international insecurities and a globalising sport dynamic.

As profound as the ethos and events of the 1936 Olympic Games may have been, back in New Zealand Lovelock's fellow sporting compatriots faced their own ideologically-laden concerns about race and ethnicity, identity, colonial supremacy, and, sporting jingoism. One of the most prevalent concerns in this regard was the air of discontent that had developed during the 1920s and 1930s about the uneasy associations between rugby union (the country's dominant sporting code), race, and politics. ${ }^{50}$ By 1936 (during the time of Lovelock's return tour 'home' in the summer of $1936 / 1937)$ these issues had given rise to serious debates that focused on the arrival of the white South African 'Springbok' Rugby Union team (scheduled for 25 th July 1937 and 29th September 1937)..$^{51}$ The tour essentially exacerbated concerns about South Africa's racial divisive policies, caused discomfort about the alignment of sport and State politics, highlighted New Zealand's own race/indigenous relations, and, placed Māori rugby under closer scrutiny. ${ }^{52}$

Rugby tours, and more precisely the debates that surrounded them, brought into sharper relief a set of complex political, social and moral issues that had been central to questions (and answers) regarding New Zealand identity and (neo)colonial participation over the latter $19^{\text {th }}$ and early part of the $20^{\text {th }}$ century. ${ }^{53}$ Against such a racially loaded and labored backdrop, Lovelock's visit (and concomitant celebration as a [white] national 'hero'), thus, cannot be considered an isolated event, but rather, read as part of a broader canvas shaded by the drawnout processes of reshaping imperial allegiances, fostering more equitable (internal) race relations, and fortifying a sense of a collective sporting ethos. NZOC's veneration of Lovelock in 1937 - which occurred prior to the arrival of the Springboks but amidst the fervent preceding political debates - was, consequently, an act that helped reaffirm to New Zealanders that despite turbulences in/on other fields its athletic vigor (and colonial allegiances elsewhere) were very much still intact. Moreover, that the success of (well educated, middle-class) citizens abroad provided an enjoyable vicarious experience for New Zealand and its sporting community. 
Though he toured around the country, speaking, running, and offering administrative and scientific advice to many factions of the sporting world, we do not know what Lovelock made of the racial and political climate during his visit. We know only that he reflected on his time here positively, and, was gracious of the hospitality offered to him by the New Zealand government. ${ }^{54}$ Though he declined invitation to work in the country, he maintained an interest in New Zealand sporting affairs and international relations. ${ }^{55}$ Coincidentally, mirroring his visit in 1936/37, his death in 1949 was also overshadowed by New Zealand and South African sporting relations. Early in the year the New Zealand All Blacks had suffered a substantial series of defeats during its tour of South Africa, and, the tragic loss of one of its finest sportsman later that same year can only have served as further discomfort to the country sports fans and followers. Lovelock's feats and heroics may be seen thus also a contrast and counter point to his 'working class' 'amateur' rugby playing contemporaries. Though there were the usual remembrances and memorial remarks made in New Zealand following his death, ${ }^{56}$ it would take some 15 years before the public had the opportunity to remember, recall, and relive Lovelock with the publication of Norman Harris' short, but evocative examination, The Legend of Lovelock. Harris' work was later followed by James McNeish's tributes, Lovelock: A novel, and, the more scholarly, Death of a dream: The fact and fictions of Jack Lovelock. ${ }^{57}$ All of which served, in their various ways, to contribute to the surmounting discourse of Lovelock as the illfated New Zealand hero that this paper takes as its starting point.

Like most historical sport figures, Lovelock's contextualization and characterization as hero, and specifically, as agent is not unproblematic. I concede Lovelock may not be considered a key agent at all. He was first and foremost an athlete, and later medical professional, who was not, ever, an official NZOC administrator. Moreover, in the pantheon of New Zealand sport history Lovelock has been afforded a nauseating reverence. ${ }^{58}$ Accordingly, Lovelock's veneration, and agency, as a sporting hero does cloud any conceptualization of his administrative actions, or for that matter, any challenge to his agency writ large. However, as I discuss, beyond sporting and intellectual capabilities (though too because of them), Lovelock had considerable utility for NZOC. In what follows I present a tri-fold assessment of Lovelock under the headings 'The professional', 'The administrator', 'the alternative and anti-'. My representations of Lovelock 
demonstrate that possibilities might exist if we move beyond conventional renderings (see 'The professional' Lovelock), extend the sorts of agency we ascribe sport figures (e.g. understanding 'The administrator' Lovelock), and create opportunities for alternative renderings to come to the fore (explored in 'The anti-' Lovelock').

\section{'The professional' Lovelock}

In the early 1930s, Jack Lovelock was already a sporting superstar and was arguably New Zealand's most revered middle-distance runner of the 1930s. Moreover, his victory in the 1500 metre event at the 1936 Berlin Olympic Games made him a predominant feature of the country's early sporting histories. He has since been continuously glorified as an eminent Olympic figure and national icon, and, he remains one of New Zealand's most popular sport heroes. ${ }^{59}$ Yet, and to invoke Hughson and Bale's sentiments about heroic figures here, treatments of Lovelock have tended toward the romanticized hagiolatries that focus too narrowly on the sporting prowess rather the broader socio-cultural concerns, matters of context, political agency, or human character writ-large. As I elaborate below, Lovelock was more than just a runner extraordinaire and athletic hero. By virtue of his athletic prowess and social connections in the United Kingdom he was an especially useful agent during the NZOC's formative years.

Lovelock was born and raised around the small New Zealand town of Timaru, educated at Timaru Boys High School, and later attended the University of Otago in Dunedin. In 1931 Lovelock left New Zealand to take up a Rhodes scholarship in medicine at Oxford. In addition to excelling in his studies at Oxford, Lovelock maintained an extensive diary of national and international sporting engagements, eventually using his athletic success to gain entrance into and maintain affiliations with the 'upper-class Oxbridge sporting set' ${ }^{60}$ Lovelock had an 'intense preoccupation with his sport', ${ }^{61}$ and by competing internationally, specifically at the 1932 and 1936 Olympic Games, earned kudos that reflected positively on NZOC. Although born and educated in New Zealand, Lovelock spent the majority of his adult life studying, working, and competing in England and the United States. Throughout England, Europe and America Lovelock's social networks and growing profile in international athletics enabled him to enjoy 
first class travel, media attention and upper-class social engagements. Indeed, Lovelock, himself, referred to it as 'a grand life'. 62

Yet, Lovelock was no amateur. At a time when his New Zealand contemporaries had to conform to the stringent amateurism criteria laid down by the athletic bodies, Lovelock enjoyed a lavish lifestyle. Lovelock may have competed as an amateur, but his extensive travel opportunities, correspondence with professional coaches, and the social accoutrements (e.g. entrance into the upper echelons on international sport) reflect more the traits and lifestyle of a consummate professional. As Colquhoun reminds us, Lovelock was a man obsessed with training and performances. He was intensely preoccupied with his sport and the insular, highly competitive, ego centric, and self-conscious world of elite athletics. Like many professional athletes of the era, he 'clearly got much satisfaction from compiling as complete a record as possible of his sporting life'. ${ }^{63}$ The professionalism Lovelock demonstrated within athletics was, to note, hardly unique. Indeed, many of his athletic contemporaries (for example, Harold Abrahams, Luigi Beccali, Parvo Nurmi) had all, in their various ways, adopted attitudes, practices, behavior that more closely aligned with a professional ethos. ${ }^{64}$ Thus, as Lovelock competes (and is read as) a 'professional', he does so not directly as an affront to the prevailing amateurism ethos, but rather, within a more amiable ideological context in which his actions, attitudes, and approach does not present an antagonist anathema to the sport (at least as far as some of his like-minded peers may be concerned).

As one commentator in New Zealand later remarked, 'Lovelock did more than win an Olympic title, he won the admiration of the sporting world for his attitude to sport'. ${ }^{65}$ At the time, Lovelock epitomized the very best of New Zealand sport and his various achievements on the world stage made him a paragon of colonial virtue. That is Lovelock's corporeal politics - his identity as a successful, white, educated male athlete - personified, and idealized, beliefs about New Zealand society and its sporting vigor. Lovelock has predominantly been remembered for his athletic prowess, academic excellence, gentlemanly upper-middle class affectations, quiet nature and untimely death in a New York subway in 1949. Despite the fact Lovelock had lived abroad and his success was rather the product of a narcissistic obsession with personal 
performance, he still cast a positive reflection to New Zealand citizens (least of all the wider world) about the vitality of the country's way of life.

\section{'The administrator' Lovelock}

Although not an official NZOC member, Lovelock was also a useful quasi-administrator, or, informal (yet informed) athletic director and liaison. ${ }^{66}$ Living predominantly in England as a Rhodes Scholar, Lovelock had also used his athletic success to gain entrance into and maintain affiliations with the upper echelons of England and American sporting fraternity. ${ }^{67}$ Additionally, his brief return to New Zealand following his Olympic success in Berlin created great interest among media, sports fans, and physical educationalists that helped promote NZOC and the Olympic movement to the public. Although New Zealand athletes had competed at previous Olympic Games, NZOC saw Lovelock's international successes as a way to promote the Olympic movement at the national level. Lovelock's athletic successes against some of the world's best milers gave him a high profile in 1930s international sporting circles. While competing in amateur events, however, Lovelock also earned money as a journalist, athlete, and radio announcer that enabled him to travel widely and compete extensively across Europe and North America. In letters to NZOC chairman Harry Amos, Lovelock provided valuable logistic and pragmatic feedback on the New Zealand team and its Olympic performances. He praised Porritt for facilitating the team's visit to London, and, also expressed concern that New Zealand athletes' continuous training on the trip over and the inadequate time allowed for acclimatisation led to poor performances. Lovelock viewed the New Zealand team's performance in the 1932 Olympic Games in Los Angeles as 'a big disappointment'. ${ }^{68}$ Consequently, he urged NZOC to get serious about providing their athletes with proper coaches, trainers, and technique specialists.

Lovelock's frank comments were a strong impetus for change in the way NZOC went about its work. Lovelock had, for example, particularly lamented the lack of financial support NZOC provided himself and Porritt as leaders of Dominion teams. 'I believe that your Committee is hopelessly ignorant', Lovelock wrote to NZOC Chairman Harry Amos, 'of the state of affairs, the 
expenses of living, and conditions of competition on this side of the world' ${ }^{69}$ Notwithstanding Lovelock's critique of NZOC, he appears to show a degree of sensitivity when he acknowledges the administrative and pragmatic issues NZOC faced. Lovelock confessed to Amos that 'such insularity of knowledge is perfectly understandable' given the 'the difficulties you are up against, both you personally, who understands how things work on this side of the world, and your Committee who obviously do not yet. Even if they did, are severely handicapped by economic factors' ${ }^{70}$ Amos and NZOC were clearly receptive to Lovelock's suggestions, and from the 1930s began to implement games management plans that were more appropriately tailored to athletes' individual needs and the broader demands of intensive international competition. $^{71}$

As a respected and knowledgeable figure, Lovelock provided a voice for athletes' concerns which before had predominantly been filtered through a Games manager or chaperone. NZOC, in return, were clearly appreciative not only to have Lovelock compete on the New Zealand team, but for him to show an interest in the affairs of the organization and its future. Lovelock was endeared by NZOC and also by the public. 'New Zealand will not only fittingly welcome the temporary return of a very distinguished son', Amos wrote to NZOC:

A son who has distinguished himself not only by his athletic prowess, but by his studies abroad. The growing importance of national physical education makes Mr. Lovelock's visit a great moment to us. His athletic achievements have been the result, not only of his natural talent, but of deep and intelligent study. The government feels that Mr. Lovelock will have something to impart of very great value, not merely in connection with track athletics but also in connection with physical education generally. ${ }^{72}$

At a time when the country was still recovering from the effects of the Depression, Lovelock's New Zealand tour provided NZOC, and local politicians, with an excellent opportunity to bask in reflected glory. Referring to Lovelock's academic prowess, Joseph Heenan, an NZOC member and senior public servant who led the Department of Internal Affairs, proclaimed, 
This is a matter of policy. If it were simply a matter of giving a great athlete a free trip I would unhesitatingly recommend against it. But Lovelock is more than merely the greatest mile runner the world has yet produced. I feel sure he is of great physical and educational value, for Lovelock has made a really scientific study of sport. ${ }^{73}$

Indeed, throughout the exhaustive tour Lovelock generously proffered his athletic and academic expertise to many members of the country's athletic, educational, and scientific communities. ${ }^{74}$ As one commentator remarked, 'New Zealand's most famous track athlete aroused great enthusiasm, and wherever he appeared to give exhibition runs the attendance were excellent. Lovelock gave we New Zealanders much good advice'. ${ }^{75}$ The attention he received, Woodfield recalls, was overwhelming, 'the public response was remarkable. Large, enthusiastic crowds welcomed him wherever he went'. ${ }^{76}$

The fervor generated by Lovelock's trip is perhaps unsurprising. As Woodfield has commented, in an era of economic uncertainty, events such as the Lovelock tour afforded New Zealand citizens respite, relaxation, and camaraderie. The intense preoccupation with Lovelock during his visit, and the iconography of Lovelock as a 'national' figure, is interesting when we consider Lovelock left New Zealand in 1931. He returned to New Zealand just once for this short tour, then, after he returned to England, moved to America, where he and his wife resided until his death. However trivial Lovelock's heroism may have seemed to some, his visit was indeed a matter of national significance. ${ }^{77}$ Agents such as Lovelock cast a critical gaze over NZOC and its affairs. A consequence of which was that NZOC was able to instigate changes that brought continued success for the country at Olympic Games.

\section{'The anti-'Lovelock}

The discussion about Lovelock's agency could finish here, and, we might be content enough to understand that he was more than just a sporting hero. Yet, and mindful of the encouragement of scholars earlier to further our critique and historiographical treatment of seminal sport stars, several questions remain. Have, for instance, we said all that we can about Lovelock as a hero?

That is, can we move beyond writing the all-too-easy hagiographies of Lovelock? Have we exhausted the limits of his heroic potential? Are their alternative renderings that might cause 
us to see his life and work differently? What possibilities are there for taking up the encouragements within sport history's various 'turns' to think and work with historical subjects, like Lovelock, more innovatively and creatively? What might our reconfigurations look like? What questions might these reconfigurations raise about agency within historical narratives? In the remainder of the paper I briefly draw on work from outside the discipline; specifically the novelty of a contemporary playwright, Dean Parker, to help ponder these points further.

In 'The man that Lovelock couldn't beat', Parker offers up a fresh, and slightly less endearing, perspective of Jack. ${ }^{78}$ Parker's approach is different to the ways Lovelock has previously been remembered. Central to Parker's (re)evaluation is the desire to highlight the pretentious nature of Lovelock's 'heroic' character, remind viewers of the myopic nature of public memory, and, cast doubt over the glorifying on the historical record (in a way similar to what Bale has achieved with Bannister). Parker's opinion of Lovelock, as expressed through the voice of the narrator (the fictitious athletic contemporary, Tommy Morehu), is worth detailing here:

I never liked Jack Lovelock. Oh, I know, I can hear you all: What sort of an attitude is that? What sort of a kiwi are you? Jack Lovelock! That hair! That smile! That "fey reticence" - or was it "alluring grace"? One or the other... That rare and perfect beauty! That dedication! That control! That sublime judgment, the "meticulously crafted sudden, destructive strike!" ... Spare me... Such a head prefect... Dux... Scholarship here, scholarship there... next to no time he's at Oxford... I hated Oxford. All those born-torule pricks of both sexes, languidly flopping their floppy hair and talking like the Queen, or even worse like Nigel Kennedy or Malcolm McLaren, prolier than thou... Couples punting on the Isis; he in fawn bags, open-necked shirt, she in silk, silk knickers, silk everything. A pint of cider and a jar of pickled onions, a mutton chop and a glass of sherry...All that. The stink of honeysuckle and a hint of Shakespeare: "Shall I compare thee to a summer's day...?" Vespers and mulled wine to follow... Fuck off...

To personify this opinion, Parker presents the audience with a new athletic figure, that of Tommy Morehu. The antithesis of Lovelock, Morehu is a young Māori, raised in a Christian orphanage in Timaru, who eventually demonstrates excellence as a middle distance runner. 
Morehu's athletic abilities eventually see him race alongside, and beat, Lovelock on several occasions. However, Morehu's background and life circumstances put him on a different track and prevent him from sharing in the luxuries and opportunities afforded to Lovelock during his illustrious sporting and academic career. Morehu eventually dies in Madrid in 1936 fighting with the Spanish Worker's Militia against Franco's fascist forces.

Parker's play urges spectators, and hopefully here sport historians, to consider the fickleness of history (particularly in its oft heavy-handed treatment/praise of historical agents) and the realm of alternative possibilities. By introducing the character of Morehu to the historical stage Parker makes a useful contribution to critiquing the centrality of Lovelock in early Olympic narratives. However, his contribution to rethinking sport historiography is more important than this. Parker succeeds in two senses. First, he offers an artistic critique to tendencies of conventional Olympic historiography that overplay the role of the sporting hero. Second, he blurs historical empiricism with creative artisanship. Parker brings Morehu to life. That is, he gives a voice to Morehu's experiences and contextualises his life within broader historical, social, and political forces. Indeed, Morehu is crafted as somewhat of an anti-hero; a figure that through one way or another either falls from grace, or, refutes the conventional stereotypes of traditionally heroism (often by being politically outspoken, and/or, counter-mainstream opinion). But, Morehu is an entirely imaginary historical character - merely a figment of Parker's imagination. Parker's intention is to use Morehu as a means to disrupt conventional historical knowledge. For example, in the final scenes, Parker reveals the possibility that Morehu also broke the fourminute mile barrier 19 years before Roger Bannister. The underlying premise of Parker's work is that characters (or agents) such as Morehu could have, and possibly did, exist. Morehu's 'existence' is important because it is through such stories and experiences that we can be caused to rethink aspects of the dominant narrative. In Parker's case ideas about 'the nation' and its ideological sporting heroes.

As a work of historical fiction, Parker's work, I accept, would not fall under the traditional remit of sport history. Yet, we should not dismiss its historiographical potential, especially, when considering what the future of the discipline might entail. Scholars are already giving serious 
consideration to how fictitious works can advance our historical criticism and practice. An excellent example is that offered by Fiona McLachlan in her examination of New Zealand's (real and imaginary) aquatic heroines. ${ }^{79}$ McLachlan argues that by examining fictional characters, and the 'fluidity' (or congruence) of their biographical narratives with non-fictional swimmers, we can transcend the limitations of narrowly conceived subject matter, and, better explore the cultural possibilities that contour the (re)production of sport figures.

Sport history has been drawn, McLachlan reminds us, unsurprisingly, to the sport hero and sport heroics. ${ }^{80}$ Taking cues from the innovation demonstrated by literary fiction, in particular the iconic novel Alex by Tessa Duder, ${ }^{81}$ and drawing on the lives, work, and experiences of characters within New Zealand swimming histories, McLachlan reveals that by overlapping, intertwining, fusing (and effectively making indistinguishable) fictional and non-fictional biographical narratives we open up innovative political space for reframing and transcending our conceptualisation of sport hero/ines. Unlike fictional counterparts, popular narratives of athletes present, in McLachlan's opinion, less opportunity to interrogate the politics of the sport hero/ine; largely because they are tied to notions of historic truth and accurate representations of 'the past'. Consequently, McLachlan challenges historian's to play with historical agents in more creative ways. 'Heroines can, and should', McLachlan asserts, 'be contradictory, messy and flawed' ${ }^{82}$

Similar thoughts about the importance of biographical fiction to advancing histographical epistemes have also been offered by Ros Barber. ${ }^{83}$ Recalling Curthoys and Docker's similar thoughts on narrative representation, ${ }^{84}$ Barber confers that innovative approaches to agents in historical narratives, at times, necessitates creative fictions. In her work on reimagining historical literary figures, Barber writes:

The methods of creative fiction allow us to escape temporarily from our received histories and bring to light the assumptions that underpin their construction. Through fiction, we have license to construct alternative narratives, rethinking histories so widely assumed to be 'true' that they have not been properly examined in the light of 
contemporary scholarship. As though trapped in bubbles of earlier, empiricist air, many apparent historical 'facts turn out to be ungrounded assumptions. ${ }^{85}$

Like with Parker, Bale, and Nathan's various efforts, McLachlan and Barber are not necessarily abandoning scholarly rigor, rather, their desire is for us to welcome and create narratives the attest to the multifarious subjectivities of athletes' lives and experiences, and not just those related to linear progressions toward success.

\section{Conclusion}

In keeping with disciplinary redirections, the intention of this paper has been to continue the efforts to critique historical agents and the purposes they serve in historical narratives, and, present possibilities to work in new ways. Agents can help historians explain social and cultural phenomenon and add useful historical voices to narratives that would otherwise remain lifeless. There are, as I demonstrated briefly with Lovelock, a range of agents (other than administrators) who affect change and continuity in the historical narrative. We can also broaden the scope of agency we might ascribe to particular individuals (in this case, moving beyond Lovelock as mere sport hero). I employed Parker's work to demonstrate how we might effectively twist the imaginary possibilities with contextualized historical memory.

As McLachlan encourages, we should try to engage creatively with the past. This is not to say that sport historians create new fictional characters (though such characters may already exist), but that they recognise the necessity of forgetting dominant narratives and popular agents in order to play in unchartered historical terrain. That is, historians need to remember anew. However, remembering anew can only happen if historians abandon the very ideas, preconceptions, and assumptions that have been the very characteristics of the oldremembering. That is, ideas such as 'nation', 'sport heroes', shared identity, and tired narratives of triumph. 
${ }^{1}$ For example, see C, Howell, 'Assessing sport history and the cultural and linguistic turn', Journal of Sport History 34, 3 (2007): 459-465; and, M. Phillips, Deconstructing Sports History: A post-modern analysis (New York: Routledge, 2006).

${ }^{2}$ See J. Bale, Roger Bannister and the four minute mile (London: Routledge, 2004); J. Hughson, 'On sporting heroes', Sport in Society 12, 1 (2009): 85-101; and D. Nathan, Saying it's so: A cultural history of the Black Sox scandal (Urbana: University of Illinois Press, 2003).

3 J. McNeish, 'Death of a dream: The fact and fictions of Jack Lovelock', in B. Patterson, eds.,Sport, society and culture in New Zealand (Wellington: Stout Research Centre, 1999), 31-37; J. McNeish, Lovelock: A novel (Auckland: Hodder \& Stoughton, 1986); G. Woodfield, Lovelock: Athlete and Doctor (Wellington: Trio Books, 2007).

${ }^{4}$ For an extensive synopsis, see D. Booth, The Field: Truth and fiction in sports history (New York: Routledge, 2005); C. Howell, 'Assessing sport history'; and M. Phillips, Deconstructing sport history.

${ }^{5}$ See J. Bale, Roger Bannister and the four minute mile; J. Bale, 'The sporting barrier: Historical and cultural interpretations of the four-minute mile', Sport in History 26, 2 (2006): 235-247; Hughson, 'On sporting heroes'; and Nathan, Saying it's so.

${ }^{6}$ A. Callinicos, Theories and Narratives: Reflections on the philosophy of history (Durham: Duke University Press, 1995); A. Callinicos, Making History: Agency, Structure, and Change in Social Theory (Leiden, The Netherlands: Koninklijke Brill, 1994); and A. Munslow, Deconstructing history ( ${ }^{\text {nd }}$ Ed.) (New York: Routledge, 1997).

${ }^{7}$ J. Bale, Roger Bannister and the four-minute mile; E. Gorn (ed.), Muhammad Ali: The People's Champion (Chicago: University of Illinois Press, 1998); Hughson, 'On sporting heroes'; S. Jackson, D. Andrews \& C. Cole, 'Race, nation and authenticity of identity: Interrogating the 'everywhere' man (Michael Jordan) and the 'nowhere' man (Ben Johnson)', Immigrants and minorities 17, 1 (1998): 82-102; G. Osmond, 'Myth-making in Australian Sport History: Re-evaluating Duke Kahanamoku's contribution to surfing', Australian Historical Studies 42, 2 (2011): 260-276; T. Runstedtler, 'Visible men: African American boxers, the new Negro, and the global color line', Radical History Review 103 (2009): 59-81; D. Wiggins, "The year of the awakening': Black athletes, racial unrest and the civil rights movement of 1968', The International Journal of the History of Sport 9, 2 (1992): 188-208.

${ }^{8}$ See C. Simpson, 'New Zealand nineteenth-century 'New Women' - On bicycles!'. International Journal of the History of Sport 18, 2 (2001): 54-77.

${ }^{9}$ See, Colquhoun, As if running on air: The journal of Jack Lovelock (Nelson: Craig Potton Publishing, 2008); McNeish, Lovelock: A novel; 'Death of a dream: The fact and fictions of Jack Lovelock'; J. Romanos, New Zealand's top 100 sports history makers (Wellington: Trio Books, 2006); Our Olympic Century (Wellington: Trio Books, 2008); and, G. Woodfield, Lovelock: Athlete and Doctor (Wellington: Trio Books, 2007).

${ }^{10}$ Ibid.

${ }^{11}$ A. Marwick, The Sixties: Cultural Revolution in Britain, France, Italy, and the United States, c.1958-1974 (Oxford: Oxford University Press, 1998); A. Marwick, The new nature of history: Knowledge, evidence, language (Chicago: Lyceum Books, 2001).

${ }^{12}$ Marwick, The Sixties, 25.

${ }^{13}$ Munslow, Theory and history: Narrative and history, 9. 
${ }^{14}$ D. Booth, Modern sport: Emergence and experiences, in C. Collins (ed.), Sport in New Zealand Society (Palmerston North: Dunmore Press, 2000), 45-63.

${ }^{15}$ D. Booth, The Field: Truth and Fiction in Sport History (New York: Routledge, 2007).

${ }^{16}$ G. A. Fine, 'Reputational entrepreneurs and the memory of incompetence: Melting supporters, partisan warriors, and images of President Harding', American Journal of Sociology, 101 (5): 1159-93.

${ }^{17}$ Callinicos, Making History: Agency, Structure and Change in Social Theory, xxiii.

${ }^{18}$ A. Levine, E. Sober, and E.O. Wright, 'Marxism and Methodological Individualism', New Left Review March/April, 162, (1987): 67-84; Callinicos, Making History, 1994.

${ }^{19}$ Callinicos, Making History, xix.

${ }^{20}$ D. Carr, 'Place and time: On the interplay of historical points of view', History and Theory, 40 (4) 153-167, 154.

${ }^{21}$ P. Clastres, 'La refondation des Jeux olympiques au Congrés de Paris (1894): Initiative privée, transnationalisme sportif, diplomatie des Ètats'; 'Les idées élitistes en 1900', Relations internationals, 111, 327-345, translation: Annemarie Jutel.

${ }^{22}$ Simon, a former president of the council for French education reform, advocated organised sports as an effective political strategy for French nobility. Simon introduced Coubertin to the idea of pacifism. Le Play essentially believed the way forward for European youth lay somewhere between English aristocracy and French revolutionarism.

${ }^{23}$ P. Clastres, 'La refondation des Jeux olympiques au Congrés de Paris (1894).

${ }^{24}$ Clastres, 'Les idées élitistes en 1900'. Journée d'étude organise par Monsieur le Professeur Guillaume Bacot et le Centre de philosophie juridique de la Faculté de droit l'Université de Cergy-Pontoise, 4 Juin, 2004. Revue française d'histoire de idées politiques, 2, (275-296), translation: Annemarie Jutel.

${ }^{25}$ See, for example, D. Andrews \& S. Jackson, Sport stars: The cultural politics of sporting celebrity (New York: Routledge, 2001); H. Chung, 'Sport star vs. Rock star in globalizing popular culture: Similarities, difference, and paradox', International Review for the Sociology of Sport 38, 1 (2003): 99-108; C. Rojek, 'Sport celebrity and the civilizing process', Sport in Society 9, 4 (2006): 674-690; G. Whannel, Media sport star: Masculinities and moralities (New York: Routledge, 20002); G. Whannel, 'Sport stars, narrativization and masculinities', Leisure studies 18, 3, (1999): 249-265.

${ }^{26} \mathrm{~J}$. Bale, Roger Bannister and the four-minute mile; The sporting barrier; Hughson, 'On sporting heroes'; Nathan, 'Saying it's so'

${ }^{27}$ Ibid.

${ }^{28} \mathrm{Ibid}, 121$.

${ }^{29}$ J. Bale, Roger Bannister and the four-minute mile, 9.

${ }^{30}$ Ibid, 135.

${ }^{31}$ Ibid, 135. 
32 Ibid, 14.

${ }^{33}$ Hughson, 'On sporting heroes'; and, J. Hughson, The making of sporting cultures. The making of sporting cultures (London: Routledge, 2011).

${ }^{34}$ Hughson, 'On sporting heroes', 85.

${ }^{35}$ Ibid, 87.

${ }^{36}$ Nathan, Saying it's so.

${ }^{37}$ Hughson, 'On sporting heroes', 85.

${ }^{38}$ Hughson, 'On sporting heroes'.

39 J. Belich, Paradise Reforged: A history of the New Zealanders from the 1880s to the year 2000 (Auckland: Allen Lane, 2001).

${ }^{40}$ B. Keys, Globalizing sport: National rivalry and international community in the 1930s (Cambridge: Harvard University Press, 2006); B. Anderson, Imagined Communities: Reflections on the origins and spread of nationalism, $2^{\text {nd }}$ Ed. (London: Verso, 1991).

${ }^{41}$ Keys, Globalizing sport.

${ }^{42}$ Keys, Globalizing sport.

${ }^{43}$ Initially proposed by Canadian Amateur Athletics Manager, Melville Marks (aka Bobby Robinson), the Empire Games (eventually renamed the Commonwealth Games) were first staged in Hamilton, Ontario in August 1930. See, K. Moore, 'Strange bedfellows and cooperative partners: The influence of the Olympic Games on the establishment of the British Empire Games', in G. Redmond, ed., Sport and Politics (Champaign, II: Human Kinetics, 1984): 109-125; K. Moore, 'One voice in the wilderness: Richard Coombes and the promotion of the Pan Brittanic Festival Concept in Australia 1891-1911', Sporting Traditions 5, 2 (1989): 180-203.

${ }^{44}$ R. Palenski, The making of New Zealanders (Auckland: Auckland University Press, 2012); G. Ryan, 'Anthropological football: Maori and the 1937 Springbok Rugby Tour of New Zealand', New Zealand Journal of History, 34, 1 (2000): 60-79; G. Kohe, At the heart of sport: The New Zealand Olympic Committee and the History of the Olympic movement in New Zealand, (Wellington: New Zealand Olympic Committee, 2011).

${ }^{45}$ NZOC, Official Minute Book, 1912-1932 (Wellington: NZOC, 1929): 155.

${ }^{46}$ Porritt had competed admirably in the 1924 Olympic Games, finishing third in the $100 \mathrm{~m}$ (in a race more widely remembered in its Chariots of Fire film replication). See: G. Woodfield \& J. Romanos, No ordinary man: The remarkable life of Sir Arthur Porritt (Wellington: Trio publishers, 2008).

${ }^{47}$ NZOC, Official Minute Book (Wellington: NZOC, 1933-1964)

${ }^{48}$ Woodfield \& Romanos, No Ordinary Man; Kohe, At the heart of sport.

${ }^{49}$ Belich, Paradise reforged; R. Palenski \& J. Romanos, Champions: New Zealand sports greats of the $20^{\text {th }}$ century (Auckland: Hodder Moa Beckett, 2000); Woodfield, Lovelock: Athlete and Doctor. 
${ }^{50}$ Ryan, 'Anthropological football'; To summarise, during the early $20^{\text {th }}$ century New Zealand sport teams had enjoyed health sporting relations with their colonial peers (namely, United Kingdom, Australia, but latterly also with South Africa). Given the implicit (though not yet officially formalised) racial policies and rhetoric that abounded in South Africa at the time, the associations with the country's sport teams however, had invariably been of most concern. ${ }^{50}$ The South African team had visited New Zealand in 1921, and, the New Zealand All Blacks had visited for their first tour in 1928. Both occasions raised questions in New Zealand (and also abroad) about the country's continued association with South Africa, and by extension, it's racially prejudice regime. The 1928 tour, for instance, had led to the New Zealand Rugby Football Union (NZRFU) being heavily criticised for their decision to exclude Māori players for the national team.

${ }^{51}$ Mulholland, 2009; Coffey \& Wood, 100 Years, Māori Rugby League; Mulholland, Beneath the Māori moon; Ryan, 'Anthropological football'. Ryan, 'Anthropological Football'. To note, South Africa eventually went on to hand New Zealand its first home series loss. The public profile and attention the debates received, also, provoked the NZRFU into seriously consider its own practices, the integral part Māori had played in the development and success of the national game, and importantly, New Zealand's invariably more progressive attitudes toward racial politics (which could certainly not be separated from its sport)

${ }^{52}$ The tour also set in place ideological and political precedents that would linger in subsequent New Zealand and South African sporting exchanges for the coming decades. For salient analysis see, M. Maclean, 'Football as social critique: Protest movements, rugby and history in Aotearoa/New Zealand', International Journal for the History of Sport 17, 2/3 (2000): 255-277; M. Maclean, “'Almost the same, but not quite...Almost the same, but not white": Maori and Aotearoa/New Zealand's 1981 Springbok Tour' Kunapipi: Journal of Postcolonial Writing 23, 1 (2001): 69-82; and, M. Maclean, 'Anti-apartheid boycotts and the affective economies of struggle', Sport in Society 13, 1 (2010): 72-91.

${ }^{53}$ Belich, Paradise reforged; Maclean, 'Football as social critique'; Palenski, The making of New Zealanders.

${ }^{54}$ NZOC, Official Minute Book

${ }^{55}$ Colquhoun, As if running on air; NZOC, Official Minute Book, 1932-1964; Palenski \& Romanos, Champions; Woodfield, Lovelock: Athlete and Doctor; Woodfield \& Romanos, No Ordinary Man.

${ }^{56}$ NZOC, Official Minute Book

${ }^{57}$ N. Harris, The legend of Lovelock (Wellington: A.H. \& A.W. Reed, 1964); McNeish, Lovelock: A novel; 'Death of a dream'.

${ }^{58}$ D. Cleaver, 'Lovelock enigma continues' New Zealand Herald (online edition), 17 May 2009. Retrieved from www.nzherald.co.nz; D. Colquhoun, As if running on air: The journals of Jack Lovelock (Nelson: Craig Potton Publishing, 2008); J. Romanos, New Zealand's top 100 sports history makers, (Wellington: Trio Books, 2006); J. Romanos, Our Olympic Century (Wellington: Trio Books, 2008).

${ }^{59}$ McNeish, 'Death of a dream'; Woodfield, Lovelock: Athlete and Doctor; Romanos, New Zealand's top 100 sports history makers; Our Olympic Century.

${ }^{60}$ Colquhoun, As if running on air, 22.

${ }^{61}$ Colquhoun, As if running on air, 29.

${ }^{62}$ Ibid, 13. 
${ }^{63}$ Colquhoun, As if running on air, 26.

${ }^{64}$ D. Gorman, 'Amateurism, Imperialism, Internationalism and the first British Empire Games', International Journal of the History of Sport 27, 4 (2010):611-634; D. Porter \& S. Wagg (eds.), Amateurism in British Sport: It matters not who won or lost? (London: Routledge, 2007); M. Ryan, Running with Fire: The true story of Chariots of Fire hero Harold Abrahams (London: Robson Press, 2012).

65 Ingram, 'Panorama of the playground - Physical fitness and the "Daily Dozen"', New Zealand Railways Magazine, 11 (10), (1937): 54-55, 55.

${ }^{66}$ Colquhoun, As if running on air; McNeish, 'Death of a dream: The fact and fictions of Jack Lovelock'.

${ }^{67}$ Colquhoun, As if running on air, 22.

68 J. Lovelock, Personal correspondence to Amos, October 10, 1934, Wellington: New Zealand Amateur Athletic Association (NZAAA) files.

69 J. Lovelock, Personal correspondence to Amos, July 19, 1936, Wellington: NZAAA files.

70 Ibid.

${ }^{71}$ NZOC, Official Minute Book 1911-1932. Wellington: NZOC

72 J. Lovelock, Personal correspondence to the NZOC, October 3, 1936, Wellington: NZAAA files.

${ }^{73}$ Cited in G. Woodfield, Lovelock: Athlete and Doctor, (Wellington: Trio Books, 2007), 94.

${ }^{74}$ NZOC, Official minute book 1933-1964. Wellington: NZOC; Colquhoun, As if running on air; Woodfield, Lovelock: Athlete and Doctor.

75 Ingram, 'Panorama of the playground', 54.

${ }^{76}$ Woodfield, Lovelock: Athlete and Doctor, 97.

${ }^{77}$ Woodfield, Lovelock: Athlete and Doctor.

${ }^{78}$ D. Parker, 'The man that Lovelock couldn't beat'. (2008). Unpublished theatrical manuscript. Held in author's possession.

${ }^{79}$ F. McLachlan, Cohesive narratives: Dissolving Aotearoa/New Zealand's heroines of water'. International Journal of the History of Sport 26, 14 (2009): 2143-2159.

${ }^{80}$ To further summarise, plentiful academic scholarship and popular writing has critiqued the meanings and makings of sports heroes, and to a lesser extent, its heroines. Yet, sports hero/ines are made, and remade, in other literary genres, such as novels, as well. These latter texts too play an important role in the (re)production of sport hero/ine discourses. As McLachlan asserts, these oft disregarded texts are rich in meaning and narrative subtleties that speak to, like academic work, critiques of sport and its practices.

${ }^{81}$ T. Duder, Alex (Auckland: Penguin, 1987)

${ }^{82}$ McLachlan, 'Cohesive narratives', 2157 
${ }^{83}$ R. Barber, 'Exploring biographical fictions: The role of imagination in writing and reading narrative', Rethinking History 14, 2 (2010): 165-187.

${ }^{84}$ A. Curthoys and J. Docker, Is history fiction? (Sydney: University of New South Wales Press, 2006), 151.

${ }^{85}$ Ibid, 166. 